\title{
THE EFFECT OF FINANCIAL RATIOS IN DETECTING FRAUDULENT COMPANY LISTED ON THE INDONESIA STOCK EXCHANGE
}

\author{
Serly* dan Eddy* \\ *Faculty of Economy, Universitas Internasional Batam \\ E-mail:serly@uib.ac.id; eddz_zz68@yahoo.com
}

\begin{abstract}
Financial statements are means used by entities to communicate financially related circumstances to interested parties both related to the entity's internal and external entities. There are various types of fraud occur in the companies. Types of fraud cases that often occur are asset misappropriation and fraudulent financial statements. Asset Misappropriation is the kind of act of fraud committed by using or taking company property for personal gain. Fraudulent financial statements are defined as fraudulent actions committed by the manager of the company which in the form of material misstatement in the financial report for the purpose to attract the investor. The fraud can be financial or non-financial. This study is meant to examine the effect of financial ratios in detecting fraudulent financial statements. The independent variable used in this study consisted of 5 variables: leverage, profitability, asset composition, liquidity and capital turn over. This study used the financial statements listed on the Indonesia Stock Exchange (IDX) as samples. The sampling technique used in this study was purposive sampling. The period range of the financial statements used in this study is 20142018 or the range of 5 years. Collected data are then tested via SPSS software.
\end{abstract}

Keywords: Fraudulent Financial Statement, Leverage, Profitability, Asset Composition, Liquidity, Capital Turn Over.

\section{INTRODUCTION}

Financial Report is a tool commonly used by entities in communicating circumstances and financial condition of company to the internal and external parties of entities. A complete financial statement is a report consisting of the cash flow statement, income statement, balance sheet, notes to the financial statements and statement of changes in equity(Kieso, Weygandt, \& Warfield, 2018). Generally Fraud is an act of illegal and violation of the law, which aims to benefit personally. IAI (2012) describes the meaning of fraud is "Every act of accounting which arise from fraudulent financial reporting either of misstatement or intentionally omission in the amounts or disclosures in financial statements to deceive the user of financial statement, or misstatements which arise from improper act to assets (often referred to the embezzlement or misuse) relating to the theft of the entity assets which result the financial statements of the entity are not presented in accordance with the accounting principles which generally accepted in Indonesia ".

In the daily lives, the fraud have occurred in various types of business, as micro business, small, medium or large. This fraud is asset misappropriation \& Fraudulent Financial Statement. Asset Misappropriation is the kind of act of fraud committed by using or taking company property for personal gain. as for using the company's money, merchandise inventory of the companies, use official cars for private purposes. While the fraudulent financial statement is the kind of act of fraud committed by concealing financial information, set the contents of the financial statements and change the content in the financial statements for the purposes to trick the readers of financial statements for corporate or personal interests.

Factors that cause the occurrence of fraud, among which in theory Fraud Triangle Cressey (1953) a fraud caused by three factor 
that is opportunity, pressure and rationalization, or commonly known as the fraud triangle. Pressure is an act of fraud due to the presence of a pressure of financial and non-financial, both derived from themselves or pressure from the organization. Opportunity is an act of fraud that occurs due to the weakness of a system in which the weakness exploited so as to be able to commit fraud. Rationality is the thought that justifies his actions as a behavior that is called fair, which in moral will be accepted in the normal society.

The era development continuously increase also increased the level of fraud, one of them is fraudulent financial statement. The act of fraudulent financial statements is cause by the companies that manipulate the financial statements of companies for the purposes to attract the interest of investors to invest their funds into the company. The cases of fraud that have happened in this world as in the case of health south corporation, Enron, WorldCom, Tyco, international commerce and banks of credit and many more other fraud cases that have happened. One of the fraud case that have happened in Indonesia is "The Scandal of manipulation financial statement in PT. Kimia Farma Tbk".

PT Kimia Farma or commonly called PT. KAEF is a drug dealer owned by government company in Indonesia. The result of audited report of 31 December 2001 showed that the management of PT Kimia Farma reported a net profit of Rp 132 billion, and this report has been audited by Hans Tuanakotta \& Mustafa (HTM). However, the Ministry of Bapepam and State-owned enterprises provide an assessment that the reported net income is exorbitant and contain manipulation components. After re-auditing, on October 3, 2002 financial statements of PT Kimia Farma 2001 restated for the results of re-audit has revealed basic error. After the financial report has been re-audit, the financial statement presented the net profit $\mathrm{Rp}$ 99.56 billion, or the amount decreased from previous financial report of Rp 32.6 billion, or $24.7 \%$ than the net profit before re-audit.
An error occurred in Kimia Farma financial statements caused by the Raw Material Industry unit that overstated the sales in the amount of USD 2.7 billion, the units Pharmaceutical Wholesalers be overstated inventory as much as $\mathrm{Rp} 8.1$ billion and overstated the sales in the amount of USD 10.7 billion, on the part of the Central Logistics unit overstated the amount inventory as much as Rp 23.9 billion. Errors in this presentation related to inventories arising from the value contained in the list of inventories prices has been increased. PT Kimia Farma, through the production director, publishes two inventories price lists on the 1st and February 3rd, 2002. The price list published on February 3rd has increased in value and have been used as the valuation of inventory for product distribution in PT Kimia Farma on 31 December 2001. Furthermore, errors in the presentation related to sales by recording over and twice the sales. Double recording was happened on the units that accountant didn't sampled it, so it successfully passed the examination of the accountant. Based on the investigation of Bapepam, it was mentioned that public accounting firm who audited the financial reports of PT Kimia Farma already obey the applicable auditing standards, but the accounting firm still fails to detect the fraudulent financial report of PT. Kimia Farma. Other than that, the public accounting firm didn't proved in helping the management to perform the fraud.

Cases of fraudulent financial statements such as PT Kimia Farma often happens in the company circles. the management is one of the perpetrator behind the fraud. Management did this fraud with the purpose to enhance financial statement and attract the investor. The financial statements show the state of a company, a good financial statement can attract the interest of investor. With the existence of these things, the management companies often commit fraudulent financial statements. To detect fraudulent financial statements can be measured using financial ratios. Financial ratios consisted of several types of financial 
ratios such as liquidity, profitability, capital turnover, leverage and asset composition.

Leverage ratio is one of the ratios used in detecting fraudulent financial statements. Companies with high leverage indicates a high risk of bankruptcy because if the company can not pay their debts. The likelihood of manager to commit fraudulent financial statements will increase if the entity had a high debt that's because the entity transfers the risk from the founder and manager of equity to creditors. Additionally manager who faces pressure of economic circumstances often commit acts of fraud in financial statements through manipulating financial reports aimed at improving the company's prospects. To detect such fraud, financial ratio used is profitability ratios. Aside from leverage and financial profitability ratio there is also liquidity, capital turnover and asset composition ratio can be used to measure fraudulent financial statement.

Research on detecting the fraud in the fraudulent company through a variety of methods already been studied. However, the results obtained have not been entirely consistent. To get more consistent results, this study has the objective to test the methods that can be use in detecting the fraud in the fraudulent company.

\section{LITERATURE REVIEW HYPOTHESIS DEVELOPMENT}

AND

\subsection{Fraudulent Company}

According to AICPA (2002),

Fraudulent company are the companies have done by: (1) Falsification, Manipulation of the report, or change the accounting records, supporting documents that use for preparing the financial statement. (2) Negligence or deliberate error in the information which will effect to the financial statements. (3) To deliberate abuse of the principles that have related to the amounts, classification, method or disclosure.

According to Spathis (2002), Fraudulent company can do the various different types and consists of various elements of manipulation that is to raise the value of sales, profit and assets or lowering cost, losses and liabilities. The following describes the types of act that fraudulent company will do:

1) Revenue recognition that does not occur

2) Revenue recognition that does not occur is common action used in the fraudulent financial statement. This action involves recording sales to manipulate income.

3) Manipulating expenses or costs

4) The act of manipulating expenditures or the cost is a deliberate fraud by manipulating costs or expenses in the financial statements. Examples of manipulation costs is to take advantage of the operational costs. Manipulating costs can help increase a company's profit.

5) Overstating assets

Overstating current assets in the financial statements is a way used in the act of fraud in the financial statements. This action causes a significant impact in the financial statements. In addition these action also have an impact on the organization's employees, clients, investors and third parties.

According to ACFE (2014), fraudulent company is defined as the companies have do the act of fraud which is usually done by the management with the ways of material misstatement in the financial statement that could cause the losses to investors and creditor. The fraud can be financial or non-financial. According to Manurung \& Hardika (2015), Fraudulent financial statement is an act of deliberate or act of negligence in prepare the financial statements in which the reported financial statements does not meet the criteria of accounting principles. Acts of omission is a deliberate act that have an influence in the decision making for the parties concerned.

Fraudulent company is the companies have do a deliberate act of errors resulting misstatements in financial statements (Annisya, Lindrianasari, \& Asmarianti, 2016). According to Sihombing dan Rahardjo (2014) as cited in Annisya et al., (2016), fraudulent 
financial statement is intentional acts or omissions in the reporting of financial statements that were reported did not meet the criteria of accounting principles. According to Septriani \& Handayani (2018), the practice of earning management is an act of manipulation financial statement made by the management as a short-term solution in order to obtain the trust of investors on their performance. Earnings management is a phenomenon that can not be avoided because the phenomenon is the basis of accrual use which uses in preparing the financial statements. Even if in terms of rational and equitable in principle, if the accrual obtained has been modified the profit will also change. Earning management can change the performance of company become better than other companies, so as the investor who do not have the precautionary principle would be gullible by the management.

\subsection{Leverage Ratio}

The leverage ratio is defined as the ratio used to measure the potency of companies or investors to utilize the borrowing money. Companies with high leverage tend to have high risk in bankruptcy problems if the company didn't have capability to pay the debts. The possibility of fraud in company will increase if the company has high debts because the owner and manager of the equity transfer the risk to the owner of the debt (Spathis, 2002). According to Dechow, Sloan, \& Sweeney (1996), the company who has high debt the possibility of manipulate the income will increase. Research shows that the possibility of transferring wealth from creditors to managers has increased with increasing in the leverage (Chow \& Rice, 1982). The management of the company will manipulate the financial report in order to fulfill the requirement of certain debts agreement. Therefore, it is proved that a high percentage of debt that may increase the possibility of fraud in the financial statements.

According to Martantya \& Daljono (2013); Putra \& Fitriany (2015); Kusuma, Perdana, \& Suranta (2017); Sunardi \& Amin (2018) have found that leverage ratio didn't has any effect to fraudulent company. Annisya et al., (2016) have found that external pressure which the calculation using the leverage ratio has no significant relation to fraudulent company. Research conducted by Ata \& Seyrek (2009) have shown opposite result from the previous research, they have found the leverage ratio which used in detecting the fraud in company has a positive relation.

In the research conducted by Kara \& Yereli (2013); Shih, Cheng, \& Wang (2011) have found that leverage ratio has a significant positive relation in detecting the fraudulent company. According to study Aghghaleh, Iskandar, \& Mohamed (2013) by using leverage ratio and sale to account receivable ratio have found that leverage ratio and sale to account receivable ratio has a significant positive relation in detecting the fraudulent company. Research conducted by Manurung \& Hadian (2013) have found the same result from the previous research, the research using the external pressure variable with a proxy of leverage ratio indicate a positive relation to fraudulent company. In the study conducted by Nakashima (2017); Sihombing \& Rahardjo (2014) have found that leverage ratio which used to detecting the fraudulent company has a positive relation. The research conducted by Dani, Ismail, \& Kamarudin (2013) have found that leverage ratio has a negative relation to fraudulent company. Research conducted by Nindito (2018) have found the same result from the previous research, the result indicate a significant negative relation to fraudulent company.

H1: There is a positive relation effect between leverage 1 ratio to fraudulent company.

H2 : There is a positive relation effect between leverage 2 ratio to fraudulent company.

\subsection{Profitability Ratio}

Profitability ratio is defined as the ratio usually use by the entity to compare the net income with the income of the company. According to Nia (2015) profitability ratio usually used for measure the capability of 
company to generate the profit. According to Kreutzfeldt and Wallace (1996) as cited in Zainudin \& Hashim (2016) the company with the low profit can distribute the incentives to management with the purpose to overstate the income or reduces the expenses, such reports indicate a significant error. According to Zainudin \& Hashim (2016) in order to optimize the functionality of their shareholders, corporate executives will manipulate the profitability ratio and it result the fraudulent financial statements.

According to the research conducted by Skousen \& Wright (2008) using the financial stability variable with a proxy of sales to total asset ratio and sales to account receivable ratio have found that profitability ratio has a positive relation in detecting the fraud in company. Furthermore, study conducted by Skousen, Smith, \& Wright (2009); Prasmaulida (2016) have found that profitability ratio has a effect and positive relation in detecting the fraud of company. The outcome of research conducted by Abbas (2017); Inayanti (2016) have found the same result from the previous research, they have found the profitability ratio has a significant influence and positive relation to fraudulent company.

According to the research Norbarani \& Rahardjo (2012); Manurung \& Hardika (2015) have found that profitability ratio didn't has effect in detecting the fraudulent company. According to the study of Darmawan \& Saragih (2017) have found opposite result from the previous research, the outcome of the study have showed that profitability ratio has a negative relation to fraudulent company.

H3 : There is a positive relation effect between profitability ratio to fraudulent company.

\subsection{Asset Composition Ratio}

Asset composition ratio is defined as the ratio used in the measurement of the percentage of current assets compared to total assets, the percentage of receivables compared to revenue and the percentage of inventory compared to the total assets. The management is more likely to manipulate the account such as sales, accounts receivable, allowance for doubtful and merchandise inventory (Schilit, 1993; Green, 1991; Loebbecke, 1989). Feroz, Park, \& Pastena (1991) explained that the management will do manipulation receivables by recording fictitious sales aimed to increase receivables. On examination fraud in the financial statements by the company, Persons (1992) explained that the company assets currently has mostly consist of inventory and accounts receivable. Because of that the company management can utilize of these accounts as a way to commit fraud in the financial statements (Spathis, 2002).

According to Dalnial, Kamaluddin, Sanusi, \& Khairuddin (2014) have found that asset composition ratio with a proxy of inventory to total asset has a positive relation effect to fraudulent company. The research conducted by Oktaviani, Karyawati, \& Arsyad (2014) have found that asset composition ratio has a significant influence and positive relation to fraudulent company. According to the research conducted by Kanapickienè \& Grundienè (2015); Putra \& Fitriany (2015); Suyanto (2009) have found that asset composition ratio has a significant positive relation in detecting the fraud in the company. Research conducted by Nia (2015) have found that asset composition ratio which used to detecting the fraudulent company has a negative relation effect.

According to the study conducted by Dani et al., (2013); Omoye \& Eragbhe (2014) have found opposite results from the previous research, the results have shown that asset composition ratio has no effect to fraudulent company.

H4: There is a positive relation effect between asset composition 1 ratio to fraudulent company.

H5: There is a positive relation effect between asset composition 2 ratio to fraudulent company.

H6: There is a positive relation effect between asset composition 3 ratio to fraudulent company. 


\subsection{Liquidity Ratio}

Liquidity ratio is the ratio used as a tool in the measurement the company potency to pay the short-term debt. According to Kreutzfeldt and Wallace (1996) as cited in Zainudin \& Hashim (2016) states that the company which was considered have a problems with the liquidity are likely to have the potential for commit fraudulent actions in financial statements rather than the company with smoothly liquidity. Generally, the company which liquidity ratio is high then the company has a greater ability to pay shortterm debt. The working capital to total assets ratio in the company is low indicate that the company has problems to settle their shortterm debt. Dalnial et al., (2014) states the manager has a high possibility to commits fraud if the company has a low liquidity ratio.

According to the research Liou (2008) have found that liquidity ratio with a proxy of working capital to total asset has a positive relation to fraudulent company. According to the research Gaganis (2009) have found that liquidity ratio has a significant influence and positive relation to fraudulent company. According to the research Ujal, Amit, Hiral, \& Rajen (2012) indicate that liquidity ratio has a positive relation in detecting the fraud in company. Furthermore, the outcome of research conducted Amara, Amar, \& Jarboui (2013); Kanapickienė \& Grundienė (2015) indicate that liquidity ratio has a positive relation in detecting the fraudulent company. In the outcome of research conducted by Ozcan (2016) have found that liquidity ratio has a negative relation in detecting the fraudulent company. Based on the result of research conducted by Nindito (2018) indicate the same result from the previous research, this research have found that liquidity ratio has a negative relation in detecting the fraud in the company.

Based on the results of research conducted by Astuti, Zuhrohtun, \& Kusharyanti (2015); Hanifa \& Laksito (2015); Kanapickienė \& Grundienė (2015) indicate the opposite result from all previous research, result of the research have found that liquidity ratio has no relation to fraudulent company.
Furthermore, research conducted Apriliana \& Agustina (2017) have found that there is no influence between liquidity ratio to fraudulent company.

H7 : There is a positive relation effect between liquidity ratio to fraudulent company.

\subsection{Capital Turnover Ratio}

Capital turnover ratio is the ratio used as a tool in measurement the company capability to generate sales by utilizing the company assets. Asides this ratio is also used as a tool to measuring management capabilities in encounter the competitive situation. According to Persons (1992), the manager who commits in fraudulent financial statement are those not competitive in rivalry using the company asset in generating sales. It creates opportunities for manager to act in fraudulent financial statements (Dani et al., 2013). Furthermore, the management who can not to compete in utilizing the company's assets to generating sales, so in order to generate incentives for managers also possible to commit acts of fraud in financial statements (Nia, 2015). According to Dalnial et al., (2014) the company have a problem in generate the sales will be likely to commits in act of fraud in the financial statements.

According to the result of research conducted Suyanto (2009) have indicate that capital turnover ratio didn't has any influence in detecting the fraud in the company. Otherwise according to the research conducted Dimitropoulos \& Asteriou (2009) have found that capital turnover ratio which used in detecting the fraud in the company has a positive relation. Research conducted Lenard \& Alam (2009) have found opposite result from the previous research, the result have indicate that the company with lower capital turnover will increase the possibility of company to commit fraud in the company because of that capital turnover ratio in detecting the fraud in the company has a negative relation.

In the research conducted by Dalnial, Kamaluddin, Sanusi, \& Khairuddin (2014) have indicate that capital turnover ratio in detecting the fraud in the company has a 
significant influence and negative relation. Furthermore, research conducted Persons (2011); Dani et al., (2013); Nia (2015) have indicate that the company will commit to fraud in the company if the capital turnover is low because of that capital turnover ratio in detecting the fraud in the company has a significant and negative relation.

H8: There is a negative relation effect between capital turnover ratio to fraudulent company.

\section{RESEARCH METHODOLOGY}

\subsection{Research Design}

Research defined as a systematic ways that are used to answer the problem that is being be inspected. There are two kind of research, the first one is primary research and the second one is secondary research. The primary research is the research use the data that collected by researchers directly rather than depending one the data that collected by the previous researchers. The method use to collect the data in primary research are interview, online survey, observation. The secondary research defined as the research use the data that collected by previous researchers. The data of secondary research collected from article, meta analyses and book. The kind of research use in this study is secondary research which mean the data of this study collected from the previous researchers (Sarwono, 2006).

In terms of objectives, this study include the type of verification research. Verification research is research used to reexamine the results of previous studies with the aim to verify correctness of the results of previous studies (Sarwono, 2006). In terms of the research approach, the study include in the cross-sectional study types. Where this research was conducted simultaneously in the same time and the data used in the study consisted of a single type of object that includes some periods (Sarwono, 2006). In terms of the presence of variable approach, the study included the type of descriptive research. Where descriptive research is the research conducted by using variable object consisting of the past and current (Sarwono, 2006).

\subsection{Research Objectives}

In this research, the object of the research is the company financial statement listed in Indonesia Stock Exchange (BEI). The period of financial statement use in this research are the period from 2014-2018. The purposive Sampling is the way of sampling method use in this research. The criteria of purposive sampling has been determined by researchers in this following conditions:

1) The companies listed in Indonesia Stock Exchange from the period 20142018.

2) The financial statements of the company from the period 2014-2018 that have been audited.

3) The companies in all sector except the company in the financial sector because the companies in the financial sector does not have the inventory in the financial statements and therefore can not be used in the measurement of the variables in the study.

4) The annual report of the company from the year 2014-2018 should have the required information in this study.

5) The company financial statement are used in this study must have the data that required by variables of this study.

\subsection{Definition of Variable Operational \\ 3.3.1. Fraudulent Company}

The dependent variable defined as the variable that is affected by the independent variables or the variable that become the consequence of emergence the independent variables (Sugiyono, 2008). The fraudulent company is the dependent variable that used in the research. The companies have do the act of fraud in the financial statements that cause the loss to third parties is the definition of the fraudulent company (Zainudin \& Hashim, 2016). Dummy variable is the benchmark of the dependent variable in the research. Where the firms that commit in the fraudulent company will be given a value 1 and the value 0 for firms that do not commit in the fraudulent company. Determining whether or not fraud in the company is determined based on the legal case like case in land, tax case and 
default case which determine in the company's annual report published officially by the Indonesian Stock Exchange. According to Zainudin \& Hashim, (2016) the formula for calculation of variable fraudulent company as the following:

Fraudulent company $=$ if companies commit fraudulent company then given the value of 1 if the company did not commit fraudulent company then given the value 0

\subsubsection{Financial Leverage}

The financial leverage ratio is the ratio used to measure the ability of companies or investors to utilize the borrowing money. The higher of financial leverage ratio, the higher of possibility that the company commit fraudulent financial statements (Spathis, 2002). According to Dechow et al., (1996) the company who has high debt the possibility of manipulate the income will increase. The companies with a high financial leverage ratio has a high risk of bankruptcy because if the company is unable to pay the interest of the loan (Zainudin \& Hashim, 2016). Based on the Zainudin \& Hashim (2016) the formula for calculating financial leverage variables are as follows:

Lev1 $=$ Total Debt $/$ Total Equity

Lev2 $=$ Total Debt $/$ Total Assets

\subsubsection{Profitability}

Profitability ratio is defined as the ratio usually use by the entity to compare the net income with the income of the company. According to Spathis (2002) the lower of profitability ratio, the higher of possibility that the company commit fraudulent financial statements. According to Zainudin \& Hashim (2016) in order to optimize the functionality of their shareholders, corporate executives will manipulate the profitability ratio and it result the fraudulent financial statements. The profitability ratio use the following formula: Prof $=$ Net Profit $/$ Revenue

Source: Zainudin \& Hashim, (2016)

\subsubsection{Asset Composition}

Asset composition ratio is defined as the ratio used in the measurement of the percentage of current assets compared to total assets, the percentage of receivables compared to revenue and the percentage of inventory compared to the total assets. According to Zainudin \& Hashim (2016) stated that the higher of asset composition ratio the higher of possibility the company to commit fraudulent financial statements. The formula used to calculate the asset composition ratios are as follows:

AC1 $=$ Current Assets $/$ Total Assets

AC2 $=$ Receivables $/$ Revenue

AC3 = Inventory / Total Assets

Source : Zainudin \& Hashim, (2016)

\subsubsection{Liquidity}

Liquidity ratio is the ratio used as a tool in the measurement the company potency to pay the short-term debt. Generally, the company which liquidity ratio is high then the company has a greater ability to pay shortterm debt. According to Dalnial et al., (2014) states the manager has a high possibility to commits fraud if the company has a low liquidity ratio. According to Zainudin \& Hashim (2016) the liquidity ratio use the following formula:

Liq $=$ Working Capital $/$ Total Assets

\subsubsection{Capital Turnover}

Capital turnover ratio is the ratio used as a tool in measurement the company capability to generate sales by utilizing the company assets. Asides this ratio is also used as a tool to measuring management capabilities in encounter the competitive situation. According to Dalnial et al., (2014) the company possibility to commits fraud in the financial statements will increase when the company has the low of capital turnover. According to Zainudin \& Hashim (2016) the capital turnover ratio use the following formula:

CAPT $=$ Revenue $/$ Total Assets

\subsection{Descriptive Statistics}

Descriptive statistics is the tool used to transform the raw data into a form that can help readers more easily grasp and understand the meaning of the data or figures presented. 
The results of observation is the main function of the descriptive statistics. Which including the frequency distribution, the percent distribution and mean (Sarwono, 2006).

\subsection{Outlier Test}

Outlier test is the tools that used to find a value of observational data deviate from the average that can cause abnormally distributed data. Outlier is data deviate much from the average value or in fact the data differs greatly from other data. The presence of data outliers in the data will lead to such analysis does not reflect the actual phenomenon. To detect the outliers of data can use the Z-Score. Data test results that exceeds the limit of 3 then the data will indicate the presence of outliers. If the results of the tests showed the number exceeds 3, then the data have cause the abnormally distributed and this kind of data is not used for subsequent testing (McClave \& Sincich, 2017).

\subsection{Multicollinearity Test}

Multicolinierity test used in the test for determine the correlation relationship between independent variables when in regression model. The independent variables should have no correlation relationship between the regression model. To detect whether Multicolinierity or not, it can be seen through the collinearity statistics.

\subsection{Hosmer and Lemeshow Test}

Hosmer and Lemeshow test usually use to test whether the model used in this study accordance with the data. When the result of Hosmer and Lemeshow test indicate significant numbers greater than 0.05 , then the model is appropriate and can be explained the independent variable have a relation to the dependent variable.

\subsection{Nagelkerke $R^{2}$ test}

Nagelkerke $\mathrm{R}^{2}$ test is a tool used to describe the relationship of independent variables and other factors that have the influence to the dependent variable. If the value Nagelkerke $\mathrm{R}^{2}$ above 0.5 it can be concluded that the influence of independent variable to the dependent variable is strong. According to Zainudin \& Hashim (2016) the formula of regression models tested were as follows:

Fraudulent company $=\mathrm{b} 0+\mathrm{b} 1(\mathrm{LEV} 1)+$ $\mathrm{b} 2(\mathrm{LEV} 2)+\mathrm{b} 3(\mathrm{PROF})+\mathrm{b} 4(\mathrm{AC} 1)+\mathrm{b} 5(\mathrm{AC} 2)$ $+\mathrm{b} 6(\mathrm{AC} 3)+\mathrm{b} 7(\mathrm{LIQ})+\mathrm{b} 8(\mathrm{CAPT})$

\section{RESEARCH FINDINGS}

\subsection{Descriptive Statistics}

In this research, secondary data is the data used in the research. The annual report that is listed in the Indonesia Stock Exchange for 5 years, from 2014 to 2018 is the object of this research. The data were processed using SPSS application. The process of selecting data samples in this study can be seen in table 1 below:

Table 1

Classification of selecting company samples data of the research

\begin{tabular}{|l|l|}
\hline Information & Total \\
\hline Companies listed in Indonesia Stock Exchange as of december 2018 & 628 companies \\
\hline Companies that are not used as sample in the study & (250) companies \\
\hline Companies that are used as sample & 378 companies \\
\hline years of research & 5 years \\
\hline Total data in research & 1890 data \\
\hline Data outlier & (343) data \\
\hline Data used in this research & 1547 data \\
\hline
\end{tabular}

Source: secondary data were studied, 2018.

The conclusion based on Table 1 is the companies listed in Indonesia Stock Exchange as of 31 December 2018 were 628 companies. Companies that are not used as a sample in the 
study were 250 companies so the total of companies that meet the criteria in the study are 378 companies. The period that used in the research is five in sequence years that is from the period of 2014 to 2018 . There is 1547 total data that used in the study and 343 data is the data outlier so the total of samples data that can still be used in the research is 1890 data. The result of descriptive statistics test after the outlier test in the following table:

Table 2

The result of descriptive statistic test

\begin{tabular}{|l|l|l|l|l|}
\hline Variables & Minimum & Maximum & Mean & Std. Deviation \\
\hline Lev 1 & -5.28509 & 7.52634 & 1.21731 & 1.25346 \\
\hline Lev 2 & .02795 & 1.35614 & .46439 & .20486 \\
\hline Profitablity & -3.17087 & 2.48701 & .02732 & .33867 \\
\hline AC 1 & .02091 & .94856 & .42459 & .21969 \\
\hline AC 2 & -.06746 & 2.39449 & .17913 & .19761 \\
\hline AC 3 & .00000 & .51977 & .13351 & .12358 \\
\hline Liq & -.57687 & .87538 & .15043 & .21648 \\
\hline CAPT & .02198 & 2.60577 & .73133 & .54824 \\
\hline SOurce: & Sata & & & \\
\hline
\end{tabular}

Source: secondary data were studied, 2018.

In Table 2 indicate that the variable leverage 1 which using the formula total debt to total equity has a minimum value is 5.28509 or $-5,285 \%$, which means there have a companies listed in Indonesia stock exchange whose equity already minus and doesn't have a ability to pay the debt. The maximum value of this variable is 7.52634 or $752,634 \%$, which means that the company is fully financed by debt amounted to 752,634\% and the equity of company is unable to cover the debt of company. other than that the mean value of leverage 1 shows by $121,731 \%$ which means that the average of companies listed in Indonesia Stock Exchange have financed by debt of $121,731 \%$ and the standard deviation is 1.25346 or $102,97 \%$, which means that the data has a lot of variety data so that data can be said has a low accuracy.

Variable leverage 2 where measurements using the total debt to total assets indicate that the minimum value is $2,795 \%$, the maximum value is $135,614 \%$ and the mean value is $46,439 \%$. These results explain that the companies listed in Indonesia Stock Exchange where the company's assets are financed using debt with the minimum value is $2,795 \%$, the maximum value is $135,614 \%$ and the mean value is $46,439 \%$. Furthermore, standard deviation of this varible is 0.20486 or $44,114 \%$, which means the variable data has many variations.

Variable profitability where measurements using the net income to revenues indicate the minimum value is 3.17087 or $-317,087 \%$, which means that companies listed in Indonesia Stock Exchange suffered losses reaching $317,087 \%$ of the companies revenue. The maximum value is 248,701\%, which means that companies listed in Indonesia Stock Exchange profit not only from the revenue of the company but also through other revenues. The results showed the mean value is $2,732 \%$ which means an average company listed on the Indonesia Stock Exchange have a low profit of the companies revenue. Furthermore, the standard deviation in the variable profitability shows that by $1.239,641 \%$.

Variable asset composition 1 where measurement using current assets to total assets. Results from the study showed that the minimum value is $2,091 \%$, the maximum value is $94,856 \%$ and the mean is $42,459 \%$. Results of the study explained that the companies listed in Indonesia Stock Exchange have at least 2,091\% current assets from total assets owned and at most 94,856\%, which means that companies have a high liquidity. Furthermore, the mean of current assets 
owned by the companies listed in Indonesia Stock Exchange amounted to $42,459 \%$ of total assets. The standard deviation of this variable indicate 0.21969 or $51,74 \%$ which means data of the variable has a lot of variety because of that data of the variable has a low accuracy.

Variable asset composition 2 by using measurements of account receivable to revenue, the result of the variable indicate that the minimum value is $-6,746 \%$, the maximum value is $239,449 \%$ and the mean value is $17,913 \%$. these result indicate the portion of credit sales in companies listed in the Indonesia Stock Exchange. Furthermore, the standard deviation of the variable is 0.19761 or $110,316 \%$. The result explain that variable has a lot of variety data.

Variable asset composition 3 by using the formula of inventory to total assets indicate that the minimum value is $0 \%$. This result explain that there are companies other than companies in financial sector listed in the Indonesia Stock Exchange that do not have inventory in their total assets. The maximum value in this research is $51,977 \%$. The result of the maximum value explained that there are companies listed in Indonesia Stock Exchange that have $51,977 \%$ inventory in the companies total asset. The mean value is $13,351 \%$, from this result it can be concluded that the average company listed on the Indonesia Stock Exchange had 13,351\% inventory in the company total assets. Furthermore, the standard deviation is 0.12358 or $92,562 \%$, which means the data of this variable is very varied.

Liquidity variables by using the formula of working capital to total assets showed the minimum value is $-57,687 \%$, the maximum value is $87,538 \%$ and the mean value is $15,043 \%$. The result of the research explained that there are companies listed in Indonesia Stock Exchange that do not have working capital or have financial problem because the minimum value is $-57,687 \%$. Furthermore, the maximum value is $87,538 \%$, which means there are companies that have a strong working capital. The mean value is $15,043 \%$, which means the average companies listed in Indonesia Stock Exchange only had working capital of $15,043 \%$. The standard deviation of the variable is 0.21648 or $143,907 \%$, which means the data of this variable has many variations.

Variable Capital Turnover by using the formula of revenue to total assets shows that the minimum value is $2,198 \%$, the maximum value is $260,577 \%$ and the mean value is $73,133 \%$. The result of the minimum value, it can be explained that the companies have a low ability to utilize the company asset in generating the sales. The maximum value explained that there are companies have the ability to use the company assets to generate the sales. The result of mean explained the average company in the Indonesia Stock Exchange reliable in utilizing the company's assets to generate sales. Furthermore, standard deviation of this variable is $74,965 \%$. That means the data of this variable has many variations.

The following is the test result of descriptive statistics for the variables that are nominal. The variabel is fraudulent financial statement. The result in the following table:

Table 3

The test results of descriptive statistics for dummy variable

\begin{tabular}{|c|l|c|c|}
\hline Category & Frequency & Percentage \\
\hline \multirow{2}{*}{ Fraudulent Company } & 0 = non fraudulent company & 1347 & $87.1 \%$ \\
\cline { 3 - 4 } & 1 = fraudulent company & 200 & $12.9 \%$ \\
\hline
\end{tabular}

Source: secondary data were studied, 2018.

The result of research in Table 3 indicate that the total of companies listed in Indonesia Stock Exchange whose company have indication of fraud. From the result of research above show that as much as $12.9 \%$ of companies listed in Indonesia Stock Exchange 
have indication of fraud so for investors and shareholders must be more careful in investing.

\subsection{Outlier Test}

Results from testing outlier to independent variable profitability, liquidity, capital turnover, leverage and asset composition indicate that there are 343 data from 1890 data detected that have outliers and are not used as a sample in the study. These data are not used as samples in this research because the data has deviated from the value of Z-Score. The criteria value of Z-Score is less than 3 or greater than -3 , if the result of outlier test is greater than 3 or less than -3 then it can be concluded the data has an outlier and cannot be used as the sample further testing. The total data that can be used as the sample after the outlier test is 1547 data.

\subsection{Multicollinearity test}

Multicollinearity test used in the test for determine the correlation relationship between independent variables when in regression model. In multicollinearity test there are 2 criteria that must be considered. The first criteria is VIF of each variable is not greater than 10 then the variable is qualified. The second criteria is the value of tolerance in the variable is greater than 0.1 then the variable is qualified. If both of these criteria is fulfilled then the variable is stated nonoccurrence of multicollinearity. The Variable used in testing multicollinearity are variable liquidity, capital turnover, leverage, profitability and asset composition. Results of testing multicollinearity in the following table:

Table 4

\begin{tabular}{|l|l|l|l|}
\hline & \multicolumn{2}{|l|}{ Collinearity Statisitics } & Conclusion \\
\cline { 2 - 4 } Variable & Tolerance & \multicolumn{1}{l|}{ VIF } & non-occurr of multicollinearity \\
\hline Profitability & .891 & 1.123 & non-occur of multicollinearity \\
\hline Leverage 1 & .177 & 5.654 & non-occur of multicollinearity \\
\hline Leverage 2 & .150 & 6.665 & non-occur of multicollinearity \\
\hline Liquidity & .211 & 4.731 & non-occur of multicollinearity \\
\hline Capital Turnover & .553 & 1.808 & non-occur of multicollinearity \\
\hline Asset Composition 1 & .182 & 5.484 & non-occur of multicollinearity \\
\hline Asset Composition 2 & .797 & 1.255 & non-occur of multicollinearity \\
\hline Asset Composition 3 & .584 & 1.713 & \\
\hline
\end{tabular}

Source: secondary data were studied, 2018.

The conclusion from the result of the table is the variables used in the study did not occur of multicollinearity. That's because all the variables tolerance is greater than 0,1 and VIF not exceed 10.

\subsection{Hosmer and Lemeshow test}

Hosmer and Lemeshow test is used to test whether the model used in this study accordance with the data. In table 5 indicate the result of Hosmer and Lemeshow test. The result can be seen in the following table:

Table 5

Hosmer and Lemeshow test

\begin{tabular}{|c|c|c|}
\hline Step & Chi-square & Sig. \\
\hline 1 & 13.043 & .060 \\
\hline
\end{tabular}

Source: secondary daa were studied, 2018.

The results of the test indicate that sig is 0.060 and greater than 0.05 . The conclusion of the test is the model can be used in detection the fraudulent company.

Table 6

The test result of influence variable independent to variable dependent

\begin{tabular}{|c|l|c|c|c|c|}
\hline \multicolumn{2}{|c|}{ Variable } & B & Sig. & $\operatorname{Exp}(\mathbf{B})$ & conclusion \\
\hline \multirow{3}{*}{ Step $1^{\mathrm{a}}$} & Lev1 & -.642 & .004 & .526 & Significant effect \\
\cline { 2 - 6 } & Lev2 & 5.355 & .000 & 211.686 & Significant effect \\
\cline { 2 - 6 } & Profitablity & .906 & .035 & 2.474 & Significant effect \\
\hline
\end{tabular}


ISSN: 2655-836X

\begin{tabular}{|l|l|c|c|c|c|}
\hline $\mathrm{AC} 1$ & -.417 & .608 & .659 & No significant effect \\
\cline { 2 - 6 } $\mathrm{AC} 2$ & -.956 & .160 & .384 & No significant effect \\
\cline { 2 - 6 } $\mathrm{AC} 3$ & -.887 & .283 & .412 & No significant effect \\
\cline { 2 - 6 } & 1.663 & .037 & 5.273 & Significant effect \\
\hline Liq & -.442 & .033 & .643 & Significant effect \\
\hline
\end{tabular}

Source: secondary data were studied, 2018.

In Table 6 indicate the result of the relation between independent variables to dependent variable. When the value of sig is less than 0.05 , it can be stated the independent variables have a influence to the dependent variable. From the results it can be concluded that the variable leverage 1, leverage 2, profitability, capital turnover, and liquidity have a influence to the variable fraudulent company so it can be concluded that $\mathrm{H} 1, \mathrm{H} 2$, $\mathrm{H} 3, \mathrm{H} 7$, and $\mathrm{H} 8$ has been accepted, whereas $\mathrm{H} 4, \mathrm{H} 5$ and $\mathrm{H} 6$ has been rejected.

\subsection{Nagelkerke $\mathbf{R}^{2}$ test}

Nagelkerke $\mathrm{R}^{2}$ test is a tool used to describe the relationship of independent variables and other factors that have the influence to the dependent variable. The result of Nagelkerke $\mathrm{R}^{2}$ test indicate that the effect of independent variables to the dependent variable only $4.8 \%$ so the remaining of $95.2 \%$ is explained by other variables that have not been used in the research. The results of the research are in Table 7 below:

Table 7

Nagelkerke $R^{2}$ test

\begin{tabular}{|c|c|c|c|}
\hline Step & $\mathbf{- 2}$ Log likelihood & Cox \& Snell R Square & Nagelkerke R Square \\
\hline 1 & $1151.042^{\mathrm{a}}$ & .026 & .048 \\
\hline
\end{tabular}

\section{CONCLUSION}

The purposes of this study is to find out the influence of independent variable leverage 1, leverage 2, liquidity, capital turnover, asset composition 1, asset composition 2, asset composition 3 and profitability to the dependent variable fraudulent company. The conclusion bases on the analysis from the previous chapter is the variable of leverage 1 and capital turnover have a negative correlation effect to fraudulent company. So, the lower of these financial ratio, the higher indication of the entity to act the fraud.

Furthermore, the variable of leverage 2 , profitability and liquidity have a positive correlation effect to fraudulent company. So the conclusion is the higher of these financial ratio, the higher of indication for the management of company to act the fraud. On the contrary, the variable of asset composition 1, asset composition 2 and asset composition 3 didn't have any significant effect to the fraudulent company. So the conclusion is the lower or the higher of these financial ratio, will have no influence in detecting the fraudulent company.

The limitations in this research are as follows:

1) There are several of the companies do not publication the annual reports during the period of 2014 - 2018 because of that these companies cannot be used in this research.

2) The lack of information about fraudulent company in Indonesian because of that it's difficult to compare or detect the fraudulent financial statement.

Also, for further research there are some of the recommendation that can be considered:

1) Expanding the period of sampling in order to get more sample in the research.

2) For the future study is expected to change the type of data used in this study, from the secondary data to primary data like questionnaire or 
interview so that the data will more accurate.

3) For the future research is expected to add more independent variable in the potential to detect the fraudulent company like fraud triangle.

\section{REFERENCES}

Abbas, A. (2017). Earnings Fraud and Financial Stability. Asia Pacific Fraud Journal, 2(1), 117-134. https://doi.org/10.21532/apfj.001.17.02. 01.010

ACFE. (2014). Report to the nations on occupational fraud and abuse. Report to the Nations on Occupational Fraud and Abuse, $1-80$. https://doi.org/http://dx.doi.org/10.2139/ ssrn. 2222608

Aghghaleh, S. F., Iskandar, T. M., \& Mohamed, Z. M. (2013). Fraud Risk Factors of Fraud Triangle and the Likelihood of Fraud Occurrence: Evidence from Malaysia. Information Management and Business Review, 6(1), $1-7$.

https://doi.org/http://dx.doi.org/10.1108/ 17506200710779521

AICPA. (2002). Consideration offraud in a Financial Statement Audit. Consideration OfFraud in a Financial Statement Audit, (Desember 15), 1-52.

Amara, I., Amar, A. Ben, \& Jarboui, A. (2013). Detection of Fraud in Financial Statements: French Companies as a Case Study Ines. International Journal of Academic Research in Business and Social Sciences, 3(5), 456-472.

Annisya, M., Lindrianasari, \& Asmarianti, Y. (2016). PENDETEKSIAN KECURANG LAPORAN KEUANGAN MENGGUNAKAN FRAUD DIAMOND Mafiana. Jurnal Bisnis Dan Ekonomi (JBE), 23(1), 72-89. Apriliana, S., \& Agustina, L. (2017). The Analysis of Fraudulent Financial Reporting Determinant through Fraud Pentagon Approach. Jurnal Dinamika Akuntansi, 9(2), 154-165.

Astuti, S., Zuhrohtun, Z., \& Kusharyanti, K.
(2015). Fraudulent financial reporting in public companies in Indonesia: An analysis of fraud triangle and responsibilities of auditors. Journal of Economics, Business \& Accountancy Ventura, $\quad 18(2), \quad 283$. https://doi.org/10.14414/jebav.v18i2.45 4

Dalnial, H., Kamaluddin, A., Sanusi, Z. M., \& Khairuddin, K. S. (2014a). Accountability in Financial Reporting: Detecting Fraudulent Firms. Procedia Social and Behavioral Sciences, 145, 61-69.

https://doi.org/10.1016/j.sbspro.2014.06 .011

Dalnial, H., Kamaluddin, A., Sanusi, Z. M., \& Khairuddin, K. S. (2014b). Detecting Fraudulent Financial Reporting through Financial Statement Analysis. Journal of Advanced Management Science, 2(1), 17-22.

https://doi.org/10.12720/joams.2.1.1722

Dani, R. M., Ismail, W. A. W., \& Kamarudin, K. A. (2013). Can financial ratios explain the occurrence of fraudulent financial statements? The 5th International Conference on Financial Criminology (ICFC), 345-354.

Darmawan, A., \& Saragih, S. O. (2017). The Impact of Auditor Quality, Financial Stability, and Financial Target for Fraudulent Financial Statement. Journal of Applied Accounting and Taxation, 2(1), 9-14.

Dechow, P. M., Sloan, R. G., \& Sweeney, A. P. (1996). Causes and Consequences of Earnings Manipulation: An Analysis of Firms Subject to Enforcement Actions by the SEC*. Contemporary Accounting Research.

https://doi.org/10.1111/j.1911-

3846.1996.tb00490.x

Dimitropoulos, P. E., \& Asteriou, D. (2009). The value relevance of financial statements and their impact on stock prices: Evidence from Greece. Managerial Auditing Journal, 24(3), 248-265. 
https://doi.org/10.1108/0268690091094 1131

Feroz, E. H., Park, K., \& Pastena, V. S. (1991). The Financial and Market Effects of the SEC ' $\mathrm{s}$ Accounting and Auditing Enforcement Releases. Journal of Accounting Research, 29, 107-142.

Gaganis, C. (2009). CLASSIFICATION TECHNIQUES FOR THE IDENTIFICATION OF FALSIFIED FINANCIAL STATEMENTS: A COMPARATIVE ANALYSIS. Intelligent Systems in Accounting, Finance \& Management: International Journal, 16(3), 207-229. https://doi.org/10.1002/isaf

Hanifa, S. I., \& Laksito, H. (2015). Pengaruh Fraud Iindicators Terhadap Fraudulent Financial Statements: Studi Empiris Pada Perusahaan Yang Listed Di Bursa Efek Indonesia (BEI) Tahun 2008-2013. Diponegoro Journal of Accounting, 4(4), 1-15. Retrieved from https://ejournal3.undip.ac.id/index.php/a ccounting/article/view/9595/9318

Inayanti, S. N. dan S. (2016). The Effect of Factors in Fraud Diamond Perspective on Fraudulent Financial Reporting. Accounting Analysis Journal, 5(3), 155162.

Kanapickiene,, R., \& Grundienè, Ž. (2015). The Model of Fraud Detection in Financial Statements by Means of Financial Ratios. Procedia - Social and Behavioral Sciences, 213, 321-327. https://doi.org/10.1016/j.sbspro.2015.11 .545

Kara, S., \& Yereli, A. N. (2013). Effectiveness of the financial ratios in the determination of the fraudulent financial statements: turkey practice. Journal of Modern Accounting and Auditing, 9(10), 1342-1353.

Kieso, D. E., Weygandt, J. J., \& Warfield, T. D. (2018). Intermediate Accounting: IFRS Edition (Third Edit). wiley.

Lenard, M. J., \& Alam, P. (2009). An Historical Perspective on Fraud Detection: From Bankruptcy Models to Most Effective Indicators of Fraud in
Recent Incidents. Journal of Forensic \& Investigative Accounting, 1(1), 1-27. https://doi.org/DOI:

Liou, F. M. (2008). Fraudulent financial reporting detection and business failure prediction models: A comparison. Managerial Auditing Journal, 23(7), 650-662.

https://doi.org/10.1108/0268690081089 0625

Manurung, D. T. H., \& Hadian, N. (2013). Detection Fraud of Financial Statement with Fraud Triangle. Proceedings of 23rd International Business Research Conference. https://doi.org/10.13140/RG.2.1.1736.6 806

Manurung, D. T. H., \& Hardika, A. L. (2015). Analysis of Factors that Influence Financial Statement Fraud in the Perspective Fraud Diamond: Empirical study on Banking Companies Listed on The Indonesia Stock Exchange year 2012 to 2014. https://doi.org/10.13140/RG.2.1.2058.8 563

McClave, J., \& Sincich, T. (2017). Statistics (thirteenth). Pearson.

Nakashima, M. (2017). Can The Fraud Triangle Predict Accounting Fraud?: Evidence from Japan, 1-37.

Nia, S. H. (2015). Financial ratios between fraudulent and non-fraudulent firms: Evidence from Tehran Stock Exchange. Journal of Accounting and Taxation, 7(3), 38-44. https://doi.org/10.5897/JAT2014.0166

Nindito, M. (2018). Financial Statement Fraud: Perspective of the Pentagon Fraud Model in Indonesia. Academy of Accounting \& Financial Studies Journal, 22(2), 1-9.

Norbarani, L., \& Rahardjo, S. N. (2012). PENDETEKSIAN KECURANGAN LAPORAN KEUANGAN DENGAN ANALISIS FRAUD TRIANGLE YANG DIADOPSI DALAM SAS NO.99. Acta Anaesthesiologica Scandinavica, 1-39. https://doi.org/10.1111/j.1399- 
6576.1985.tb02224.x

Oktaviani, E., Karyawati, G., \& Arsyad, N. (2014). Factors Affecting Financial Statement Fraud: Fraud Triangle Approach. 3rd Economics \& Business Research Festival, 1-17.

Omoye, A. S., \& Eragbhe, E. (2014). Accounting Ratios and False Financial Statements Detection: Evidence from Nigerian Quoted Companies. International Journal of Business and Social Science, 5(7(1)), 206-215.

Özcan, A. (2016). Firm Characteristics and Accounting Fraud: A Multivariate Approach (Firma Karakteristikleri ve Muhasebe Hilesi: Çok Değişkenli Yaklaşım). Journal of Accounting, Finance and Auditing Studies, 2(2), 128144. Retrieved from http://www.jafas.org

Persons, O. S. (1992). Using financial statement data to identify Factor Associated with Fraudulent Financial Reporting. Journal of Applied Business Research (JABR), 11(3), 38-46.

Prasmaulida, S. (2016). Financial Statement Fraud Detection Using Perspective of Fraud Triangle Adopted By Sas No. 99. Asia Pacific Fraud Journal, 1(2), 317 335.

https://doi.org/10.21532/apfj.001.16.01. 02.24

Putra, A. P., \& Fitriany. (2015). FRAUD TRIANGLE (PRESSURE, OPPORTUNITY, AND RATIONALIZATION) AND THE LEVEL OF ACCOUNTING IRREGULARITIES IN INDONESIA. Journal of Experimental Psychology: General, (1), 1-28.

Sarwono, J. (2006). Metode Penelitian Kuantitatif (pertama). Yogyakarta: Graha Ilmu.

Septriani, Y., \& Handayani, D. (2018). Mendeteksi Kecurangan Laporan Keuangan dengan Analisis Fraud Pentagon . Jurnal Akuntansi Keuangan Dan Bisnis, 11(1), 11-23.

Shih, K.-H., Cheng, C.-C., \& Wang, Y. H. (2011). FINANCIAL INFORMATION
FRAUD RISK WARNING FOR MANUFACTURING INDUSTRY USING LOGISTIC REGRESSION AND NEURAL NETWORK. Romanian Journal of Economic Forecasting, 14(1), 54-71.

Sihombing, K. S., \& Rahardjo, S. N. (2014). Ananlisis Fraud Diamond Dalam Mendeteksi Financial Statement Fraud: Studi Empiris Pada Perusahaan Manufaktur Yang Terdaftar di Bursa Efek Indonesia (BEI) Tahun 2010-2012. Diponegoro Journal of Accounting, 03(2), 1-12. https://doi.org/10.6007/IJARAFMS/v5$3 / 1823$

Skousen, C. J., Smith, K. R., \& Wright, C. J. (2009). DETECTING AND PREDICTING FINANCIAL STATEMENT FRAUD: THE EFFECTIVENESS OF THE FRAUD TRIANGLE AND SAS NO. 99. International Journal for Researcher Development (Vol. 13). https://doi.org/http://dx.doi.org/10.1108/ MRR-09-2015-0216

Skousen, C. J., \& Wright, C. J. (2008). Contemporaneous Risk Factors and the Prediction of Financial Statement Fraud. SSRN. https://doi.org/10.2139/ssrn.938736

Spathis, C. T. (2002). Detecting false financial statements using published data: some evidence from Greece. Managerial Auditing Journal, 17(4), 179-191. https://doi.org/10.1108/0268690021042 432

Sugiyono. (2008). Metode penelitian Kuantitatif, Kualitatif dan R \& D. Bandung: Alfabeta.

Suyanto, S. (2009). Fraudulent Financial Statemen Evidence from Statement on Auditing Standard No. 99. Gadjah Mada International Journal of Business, 11(1), 117-144.

https://doi.org/10.1093/oxfordhb/97801 99235476.003.0007

Ujal, M., Amit, P., Hiral, P., \& Rajen, P. (2012). Detection of Fraudulent Financial Statement in India: An 
Global Financial Accounting Journal, Vol. 4, No. 2, Oktober 2020

ISSN: $2655-836 \mathrm{X}$

Exploratory Study. In Proceedings of the

2nd International Conference on

Enterprise Systems \& Accounting (ICESA 2005), 4, 1-19.

Zainudin, E. F., \& Hashim, H. A. (2016).

Detecting fraudulent financial reporting using financial ratio. Journal of Financial Reporting and Accounting, 14(2),

266-278. https://doi.org/10.1108/JFRA-05-20150053 